\title{
ANALISIS HUTANG TERHADAP KINERJA PT. MULTI SUKSES MAKMUR PERKASA
}

\author{
Jemmy Poandy, SE \\ Program Studi Diploma IV \\ Akuntansi Keuangan Publik \\ Politeknik Katolik Saint Paul Sorong \\ Email : jpoandy@yahoo.co.id
}

\begin{abstract}
Abstrak
Tujuan penelitian ini adalah untuk mengetahui bagaimana kinerja perusahaan dalam menutupi hutang perusahaan. Data diperoleh langsung dari perusahaan PT. Multi Sukses Makmur Perkasa penulis menganalisis dengan menggunakan 3 rasio yaitu Rasio Likuiditas, Leverage dn Profitabilitas. Data yang diperoleh berupa Laporan Keuangan Neraca dan Laba-Rugi. Hasil penelitian ini menunjukan adanya penurunan rasio baik likuiditas maupun profitabilitas pada tahun 2015, dan kenaikan rasio leverage pada tahun 2015, namun penurunan dan kenaikan rasio ini tidak berarti perusahaan tidak ilikuid sebab perusahaan masih dapat membayar hutang-hutangnya dengan baik. Karena pada tahun 2015 laba perusahaan meningkat sebesar 20,28\%.
\end{abstract}

Kata kunci : Hutang, Likuiditas, Leverage, Profitabilitas

\section{PENDAHULUAN}

\section{Latar Belakang}

PT.Multi Sukses Makmur Perkasa merupakan perusahaan yang bergerak dibidang usaha dagang. Keuntungan merupakan persyaratan kelangsungan hidup bagi perusahaan. Faktor yang mempengaruhi besar kecilnya laba usaha. Modal bagi perusahaan adalah sumber dana yang mendukung dan menjamin kelangsungan kegiatan perusahaan. Dalam mengembangkan usahanya PT. Multi Sukses Makmur Perkasa memiliki keterbatasan modal sehingga harus melalukan pinjaman dari pihak luar baik dalam bentuk hutang jangka pendek maupun jangka panjang, untuk itu manajemen perusahaan dituntut untuk bekerja keras agar pengunaan modal tersebut dapat memberikan keuntungan bagi perusahaan, sehingga perusahaan dapat berkembang dengan baik dan mampu membayar hutang kepada kreditur. Terlebih lagi untuk perusahaan dibidang usaha dagang yang memiliki banyak pesaing, manajemen perusahaan harus lebih bekerja keras dalam menentukan penggunaan hutang yang dimiliki agar perusahaan dapat meningkatkan laba perusahaan.

PT. Multi Sukses Makmur Perkasa selama 2 tahun (2014-2015), Operasional perusahaan sebagian besar dibiayai oleh hutang atau pinjaman. Hutang dalam jumlah besar dan modal saham yang lebih kecil, dari itu penulis mengambil judul
"Analisis Hutang Terhadap Kinerja PT. Multi Sukses Makmur Perkasa"

\section{Rumusan Masalah}

Berdasarkan latar belakang masalah, maka masalah-masalah yang akan menjadi pokok pembahasan pada penelitian ini adalah: "Bagaimana kinerja perusahaan dalam melunasi hutangnya dalam kurun waktu 2 tahun yaitu 2014 dan 2015 jika dianalisis menggunakan rasio likuiditas, leverage dan profitabilitas"

\section{Tujuan Penelitian}

Tujuan merupakan target atau sasaran yang ingin dicapai dalam melakukan suatu kegiatan. Tujuan dari penelitian ini adalah Untuk mengetahui kinerja perusahaan dalam melunasi hutangnya dalam kurun waktu 2 tahun yaitu 2014 dan 2015 jika dianalisis menggunakan rasio likuiditas, leverage dan profitabilitas.

\section{TINJAUAN PUSTAKA}

Hutang sering disebut juga sebagai kewajiban yang harus dibayar oleh perusahaan kepada pihak lain. Hutang digunakan perusahaan untuk membiayai berbagai macam kebutuhan yang diperlukan oleh perusahaan. Hutang Jangka Pendek 
adalah hutang yang diharapkan akan dilunasi dalam waktu satu tahun dengan menggunakan sumbersumber yang merupakan aktiva lancar atau yang menimbulkan utang lancar itu sendiri. Hutang jangka panjang adalah kewajiban kepada pihak tertentu yang harus dilunasi dalam jangka waktu lebih dari satu periode akuntansi (1Th) dihitung dari tanggal pembuatan laporan posisi keuangan. Pembayaran dilakukan dengan kas namun dapat diganti dengan aset tertentu.

Kinerja keuangan merupakan gambaran dari pencapaian keberhasilan perusahaan dapat diartikan sebagai hasil yang telah dicapai atas berbagai aktivitas yang telah dilakukan. Dapat dijelaskan bahwa kinerja keuangan adalah suatu analisis yang dilakukan untuk melihatsejauh mana suatu perusahaan telah melaksanakan dengan menggunakan aturan-aturan pelaksanaan keuangan secara baik dan benar (Irham Fahmi 2013).

Laba Usaha, Setiap perusahaan dalam menjalankan usahanya bertujuan untuk memperoleh laba semaksimal mungkin. Informasi mengenai laba sebuah perusahaan dapat diperoleh dalam laporan keuangan yaitu, laporan laba/rugi. Informasi tersebut digunakan oleh pihak intern maupun ekstern perusahaan untuk membuat keputusan. Suatu perusahaam akan dikatakan berhasil apabila dalam kegiatan operasionalnya memperoleh laba. Laba dimanfaatkan sebagai ukuran untuk menilai prestasi perusahaan atau sebagai dasar ukuran penilaian yang lain, seperti laba per lembar saham. Unsur-unsur yang menjadi bagian pembentuk laba adalah pendapatan dan biaya. Dengan mengelompokkan unsur-unsur pendapatan dan biaya. Dengan mengelompokkan unsur-unsur pendapatan dan biaya, akan dapat diperoleh hasil pengukuran laba yang berbeda antara lain; laba kotor, laba operasional, laba sebelum pajak dan laba bersih.

Rasio likuiditas yaitu rasio-rasio yang digunakan untuk mengukur kemampuan perusahaan untuk memenuhi kewajiban finansial jangka pendeknya atau kewajiban yang harus segera dipenuhi. Jika perusahaan mampu memenuhi kewajiban keuangan tepat pada waktunya maka perusahaan tersebut dalam keadaan likuid, sebaliknya jika perusahaan tidak dapat memenuhi kewajiban keuangan jangka pendeknya, berarti perusahaan tersebut dalam keadaan ilikuid.

Rasio leverage atau biasa juga disebut dengan rasio hutang digunakan untuk mengukur seberapa besar aktiva yang dimiliki perusahaan berasal dari hutang atau modal, sehingga dengan rasio ini dapat diketahui posisi perusahaan dan kewajibannya yang bersifat tetap kepada pihak lain serta keseimbangan nilai aktiva tetap dengan modal yang ada. Rasio ini juga memberi beberapa indikasi tentang kemampuan perusahaan menghadapai kerugian tanpa menganggu kepentingan kreditur.Semakin tinggi rasio utang terhadap total asset perusahaan, semakin tinggi risiko perusahaan tidak mampu membayar kewajiban yang jatuh tempo.

Rasio profitabilitas mengukur laba dan keberhasilan operasi suatu perusahaan dalam suatu periode waktu tertentu. Laba (atau mungkin rugi) mempengaruhi kemampuan perusahaan untuk mendapat pendanaan utang atau ekuitas.Selain itu juga mempengaruhi posisi likuiditas perusahaan dan kemampuan perusahaan untuk berkembang.Oleh karena itu, baik kreditor maupun investor, sangat tertarik untuk mengevaluasi kemampuan perusahaan memperoleh laba atau profitabilitas.

\section{METODE PENELITIAN}

Penelitian yang bersifat ilmiah menghendaki dipergunakannya metode yang dapat dipertanggung jawabkan secara ilmiah. Dengan demikian metode penelitan merupakan suatu hal yang mendasar dan harus ada dalam penyusunan karya ilmiah sekaligus merupakan kegiatan untuk mengembangkan dan mengkaji suatu data kebenaran pengetahuan secara ilmiah.

\section{Jenis Penelitian}

Dalam melakukan suatu penelitian sangat perlu dilakukan perencanaan dan perancangan penelitian, agar penelitan dapat berjalan dengan baik dan sistematis. Jenis penelitian ini ditujukan untuk mengevaluasi bagaimana kinerja perusahaan dalam melunasi hutangnya. Penelitan ini bersifat membandingkan keberadaan suatu variable atau lebih pada dua sampel yang berbeda.

\section{Jenis dan Sumber Data}

Jenis data yang digunakan dalam penelitian ini adalab data sekunder, yaitu data yang diperoleh, dikumpulkan dan diolah terlebih dahulu oleh pihak lain. Data tersebut terdiri dari data-data laporan keuangan (laporan rugi-laba dan Neraca) perusahaan PT. Multi Sukses Makmur Perkasa dan pengumpulan data dengan mencari data-data mengenai kinerja keuangan PT. Multi Sukses Makmur Perkasa pada tahun 2014 sampai dengan tahun 2015.

Sumber data yang digunakan adalah sumber data sekunder yang diperoleh dari pihak kedua berupa laporan keuangan PT. Multi Sukses Makmur Perkasa khususnya neraca dan lapora rugi-laba.

\section{Metode Pengumpulan Data}

Dalam penelitian ini metode pegumpulan data yang digunakan adalah sebagai berikut: 
1. Dokumentasi

2. Studi Kepustakaan

3. Interview

\section{Teknik Analisis}

Teknik analisis data yang digunakan adalah deskriptif kuantitatif persentase. Deskriptif merupakan tulisan yang berisi

\section{PEMBAHASAN DAN HASIL}

\section{Penyajian Data}

Dalam bab ini penulis akan melakukan analisis bagaimana kinerja perusahaan dalam melunasi hutangnya dengan menggunakan rasio likuiditas, leverage dan profitabilitas pada PT.Multi Sukses Makmur Perkasa untuk periode 31 Desember 2014, Desember 2015. Berdasarkan data yang berhasil di kumpulkan maka penulis menganalisis dan menguraikan rasio:

1. Rasio Likuiditas berdasarkan Laporan Keuangan PT. Multi Sukses Makmur Perkasa periode tahun 2014-2015. Pada rasio ini penulis akan menghitung jumlah aktiva dan pasiva pada tahun periode bersangkutan kemudian membandingkan kedua jumlah tersebut untuk mendapatkan hasil perhitungan berupa rasio likuiditas yang terdiri dari:
a. Rasio Lancar
b. Rasio Cepat

2. Rasio leverage berdasarkan Laporan Neraca PT.Multi Sukses Makmur Perkasa periode tahun 2014-2015. Pada rasio ini penulis akan menghitung hutang dan aktiva tahun periode bersangkutan kemudian membandingkan jumlah-jumlah tersebut untuk mendapatkan hasil perhitungan berupa rasio leverage yang terdiri dari :

a. Total Debt To Equity Ratio

b. Debt Ratio

3. Rasio Profitabilitas berdasarkan Laporan Laba Rugi PT.Multi Sukses Makmur Perkasa periode tahun 2014-2015. Pada rasio ini penulis akan menghitung pendapatan, beban, untung dan rugi perusahaan pada tahun periode bersangkutan kemudian membandingkan jumlah-jumlah tersebut untuk mendapatkan hasil perhitungan berupa rasio profitabilitas yang terdiri dari :

a. Gross Profit Margin ( GPM )

b. Net Profit Margin ( NPM)

c. Return on Asset ( ROA )

\section{Data Laporan Keuangan}

Berikut penulis menyajikan laporan keuangan PT.Multi Sukses Makmur Perkasa secara komparatif tahun 2014 dan 2015. 
Tabel 4.1.

Laporan Posisi Keuangan PT. Multi Sukses Makmur Perkasa

\begin{tabular}{|c|c|c|c|c|}
\hline & PT. Multi Sukses Ma & kmur Perkasa & & \\
\hline & Laporan Posisi Keuan & $\operatorname{yan}$ (Diringkas) & & \\
\hline & 31 Desem & & & \\
\hline & & & $\begin{array}{c}\text { Kenaikan/ Penurunan } \\
\text { tahun } 2015\end{array}$ & selama \\
\hline & 2014 & 2015 & Perubahan & $\%$ \\
\hline Aktiva & & & & \\
\hline Aktiva Lancar & & & & \\
\hline Kas dan Bank & $\mathrm{Rp} \quad 663.036 .597$ & $\mathrm{Rp} \quad 610.549 .063$ & $\mathrm{Rp} \quad(52.487 .534)$ & $-9 \%$ \\
\hline Persediaan barang & Rp 9.175 .656 .926 & $\mathrm{Rp} \quad 16.783 .771 .452$ & Rp 7.608.114.526 & $45 \%$ \\
\hline Piutang Dagang & $\mathrm{Rp}$ & $\mathrm{Rp}$ & $\mathrm{Rp}$ & \\
\hline Pajak Dibayar dimuka & $\mathrm{Rp} \quad 32.873 .302$ & $\mathrm{Rp} \quad 651.982 .034$ & $\mathrm{Rp} \quad 619.108 .732$ & $95 \%$ \\
\hline Total Aktiva Lancar & Rp 9.871 .566 .825 & Rp 18.046.302.549 & Rp 8.174.735.724 & $45 \%$ \\
\hline Aktiva Tetap & & & & \\
\hline Harga Perolehan & $\mathrm{Rp} \quad 1.110 .417 .908$ & $\mathrm{Rp} \quad 1.110 .417 .908$ & - & \\
\hline Akm. Penyusutan & $\mathrm{Rp} \quad(746.738 .616)$ & $\mathrm{Rp} \quad(880.981 .866)$ & $\mathrm{Rp} \quad(134.243 .250)$ & $15 \%$ \\
\hline Total Aktiva Tetap & $\begin{array}{ll}\text { Rp } & 363.679 .292\end{array}$ & Rp $\quad 229.436 .042$ & Rp (134.243.250) & $-59 \%$ \\
\hline Total Aktiva & Rp 10.235.246.117 & Rp 18.275.738.591 & Rp 8.040.492.474 & $44 \%$ \\
\hline Kewajiban & & & & \\
\hline Hutang Bank & & $\mathrm{Rp}$ & - & \\
\hline Hutang Dagang & Rp $\quad 5.348 .840 .405$ & $\mathrm{Rp} \quad 12.468 .740 .968$ & Rp 7.119.900.563 & $57 \%$ \\
\hline Hutang Pajak & 100.297 .357 & 28.315 .276 & $\operatorname{Rp} \quad(71.982 .081)$ & $-254 \%$ \\
\hline Hutang Lain-lain & - & $\mathrm{Rp}$ & - & \\
\hline Total Kewajiban & Rp 5.449.137.762 & Rp 12.497.056.244 & Rp 7.047.918.482 & $56 \%$ \\
\hline Modal & & & & \\
\hline Modal Saham & $\mathrm{Rp} \quad 1.000 .000 .000$ & $\mathrm{Rp} \quad 1.000 .000 .000$ & $\mathrm{Rp}$ & $0 \%$ \\
\hline Laba ditahan & Rp $\quad 2.811 .059 .889$ & $\mathrm{Rp} \quad 3.555 .536 .360$ & $\mathrm{Rp} \quad 744.476 .471$ & $21 \%$ \\
\hline Laba Tahun Berjalan & 975.048 .466 & $\mathrm{Rp} \quad 1.223 .145 .987$ & Rp $\quad 248.097 .521$ & $20 \%$ \\
\hline Total Modal & Rp 4.786 .108 .355 & $\begin{array}{ll}\text { Rp } & 5.778 .682 .347\end{array}$ & $\begin{array}{|ll|}\text { Rp } & 992.573 .992 \\
\end{array}$ & $17 \%$ \\
\hline Total Kewajiban \& Modal & Rp 10.235.246.117 & Rp 18.275.738.591 & Rp 8.040.492.474 & $44 \%$ \\
\hline
\end{tabular}

Sumber : PT.Multi Sukses Makmur Perkas 
Tabel 4.2

Laporan Laba Rugi PT. Multi Sukses Makmur Perkasa

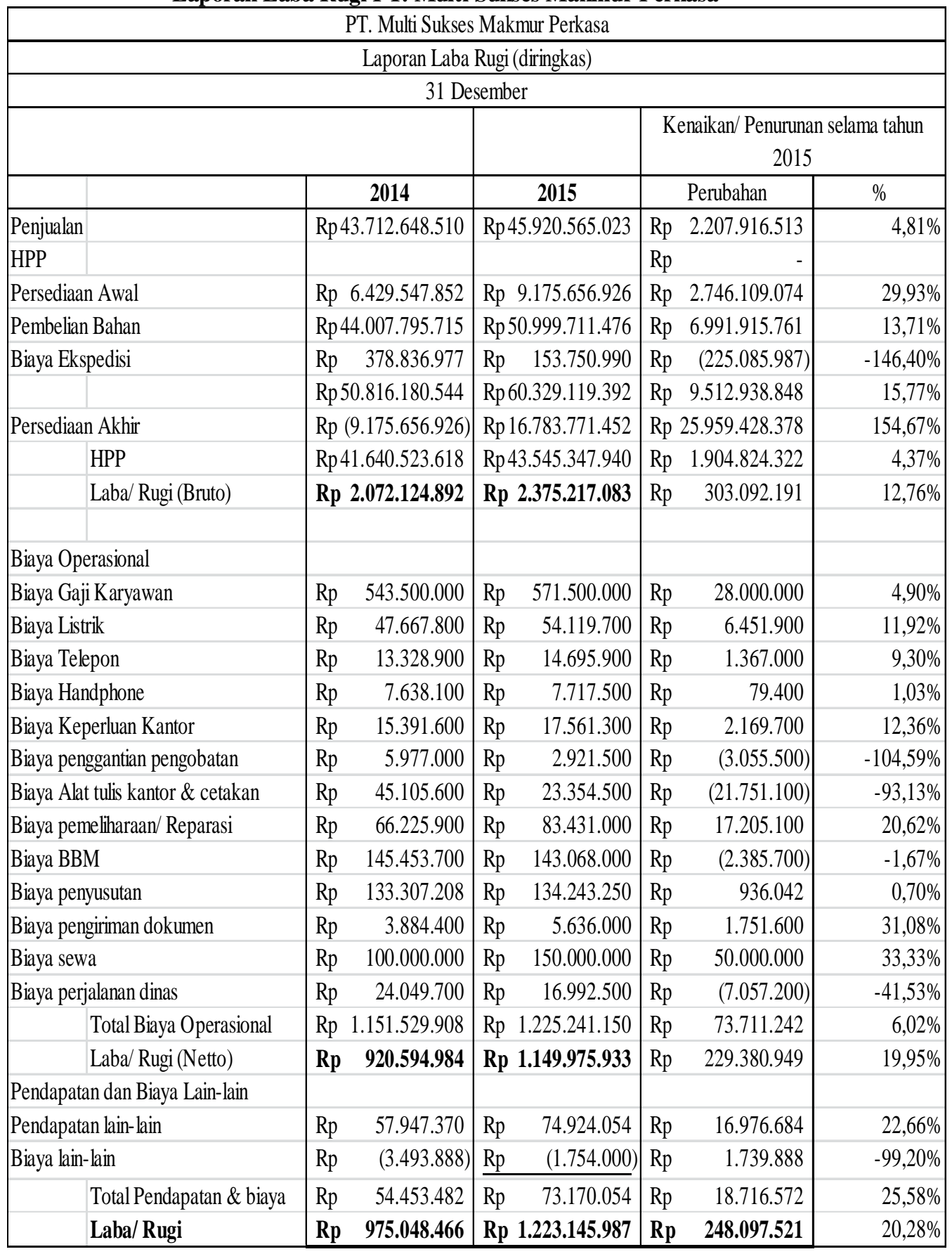

Sumber : PT.Multi Sukses Makmur Perkasa

Tabel 4.1 diatas menunjukkan analisis komparatif laporan perubahan posisi keuangan PT.Multi Sukses Makmur perkasa dari tahun 2014-2015. Pada aktiva lancar, persediaan barang dagang naik 45\%, sedangkan kas perusahaan pada tahun 2015 mengalami penurunan sebesar $159 \%$ dan hutang dagang yang mengalami kenaikan sebesar $57 \%$ selain itu pajak dibayar dimuka juga mengalami kenaikan sebesar $95 \%$. 
Dibandingkan dengan aktiva lancar yang naik $45 \%$, aktiva tetap perusahaan turun sebesar 59\%, hal ini dikarenakan oleh perubahan akumulasi penyusutan yang terus meningkat tiap tahun dengan tujuan agar beban penyusutan dapat menurun.

Pada sisi pasiva perusahaan menunjukkan kewajiban perusahaan mengalami kenaikan sedangkan modal saham perusahaan tetap dan laba ditahan yang kenaikannya tidak sebanding dengan kenaikan kewajiban perusahaan pada tahun 2015.Kenaikan kewajiban perusahaan disebabkan oleh besarnya hutang dagang yang menimbulkan persediaan barang pada aktiva juga naik.

Tabel 4.2 diatas menunjukkan analisis komparatif Laba-Rugi PT.Multi Sukses Makmur perkasa dari tahun 2014-2015. Penjualan perusahaan tidak mengalami kenaikan nilai yang signifikan hanya sebesar $4,81 \%$ selain itu biaya operasional naik sebesar $6,02 \%$ dan pendapatan selain penjualan mengalami kenaikan sebesar $22,66 \%$ sehingga laba pada perusahaan mengalami tidak mengalami kenaikan yang signifikan hanya sebesar $20,28 \%$.

Dari keterangan diatas dapat disimpulkan bahwa perusahaan tidak dapat memaksimalkan penjualannya walaupun persediaan barang dari peningkatan pembelian telah dimaksimalkan dan juga biaya operasional yang seharusnya dapat menunjang penjualan perusahaan, namun kenaikan ini tidak diikuti oleh kenaikan penjualan yang besar sehingga perusahaan hanya mengalami kenutungan sebesar Rp 248.097.521.

\section{Perhitungan Rasio Likuiditas}

1. Rasio Lancar ( Current Ratio )

Perhitungan rasio lancar PT.Multi Sukses Makmur Perkasa adalah sebagai berikut :

$$
\begin{aligned}
& \text { Current Ratio } \\
& =\frac{\text { Aktiva Lancar }}{\text { Kewajiban Lancar }} \times 100 \% \\
& =181 \%
\end{aligned}
$$

Current Ratio 2015

$=\frac{\operatorname{Rp} 18.046 .302 .549,-}{\operatorname{Rp~12.497.056.244,-}} \times 100 \%$

$$
=144 \%
$$

Dari hasil perhitungan rasio lancar yaitu dengan membandingkan aktiva lancar dan kewajiban lancar pada PT.Multi Sukses
Makmur Perkasa tahun 2014 menunjukkan hasil rasio lancersebesar $188 \%$ hal ini menunjukkan bahwa setiap Rp.1,00 hutang lancar dijamin dengan Rp. 1.88 aktiva lancar.

Untuk tahun 2015 rasio lancar yaitu dengan membandingkan aktiva lancar dan kewajiban lancar pada PT.Multi Sukses Makmur Perkasa tahun 2014 menunjukkan hasil rasio lancar sebesar $144 \%$ yang berarti bahwa setiap Rp.1,00 hutang lancar dijamin dengan Rp.1,44 aktiva lancar. Rasio lancar pada tahun 2015 mengalami penurunan sebesar $40 \%$ dari tahun 2014.Penurunan ini disebabkan oleh kenaikan persentase pinjaman/ hutang perusahaan sebesar 56\% yang lebih besar dibandingkan dengan persentase kenaikan aktiva perusahaan yang hanya sebesar $44 \%$.

\section{Rasio Cepat ( Acid Test Ratio )}

Perhitungan rasio cepat PT.Multi Sukses Makmur Perkasa adalah sebagai berikut :

$$
\begin{aligned}
& \text { Acid Test Ratio } \\
& =\frac{\text { Aktiva lancar }- \text { Persediaan }}{\text { Kewajiban lancar }} \times 100 \% \\
& \text { Acid Test Ratio } 2014 \\
& \frac{\text { Rp 9.871.566.825 - Rp 9.406.228.921,-- }}{\operatorname{Rp~5.449.137.762,-}} \times 100 \% \\
& =9 \% \\
& =6 \%
\end{aligned}
$$

Dari hasil perhitungan rasio cepat yaitu dengan membandingkan aktiva lancar selain persediaan dan kewajiban lancar pada PT.Multi Sukses Makmur Perkasa tahun 2014 menunjukkan hasil acid test ratio sebesar $9 \%$ hal ini menunjukkan bahwa setiap Rp.1,00 hutang lancar dijamin dengan Rp. 0,09aktiva lancar selain persediaan.

Untuk tahun 2015 rasio cepat yaitu dengan membandingkan aktiva lancar selain persediaan dan kewajiban lancar pada PT.Multi Sukses Makmur Perkasa tahun 2015 menunjukkan hasil acid test ratio sebesar $6 \%$ yang berarti bahwa setiap Rp.1,00 hutang lancar dijamin dengan Rp.0,06 aktiva lancar selain persediaan. Rasio cepat pada tahun 2014 mengalami 
penurunan sebesar3\% atau Rp.0,03 dari tahun 2013.

Dari hasil analisis kedua rasio likuiditas diatas, maka dapat disimpulkan bahwa PT.Multi Sukses Makmur Perkasa dalam kurun waktu 2014 s/d 2015 mempunyai tingkat likuiditas yang sangat rendah karena aktiva lancar yang menjamin hutang lancar sangat kecil dan bahkan menurun sebesar Rp. 0,40 ditahun 2015.

Kas yang terlalu sedikit dapat memperlambat kegiatan perusahaan dan menghambat dalam memenuhi kewajibankewajibannya, untuk itu perusahaan senantiasa menjaga dan meningkatkan kas yang tersedia agar dapat memenuhi kewajibannya dengan cara mengerahkan bagian marketing untuk dapat menaikkan hasil penjualan sehingga kas bertambah dan persediaan barang dagang dapat berkurang, dengan begitu perputaran keuangan pada perusahaan dapat teratasi dan likuiditas perusahaan dapat pulih.

\section{Perhitungan Rasio Leverage}

\section{Total Debt To Equity Ratio (TD Equity)}

TD Equity $\frac{\text { Hutang Lancar+Hutang Jangka Panjang }}{\text { Modal }} \mathrm{x}$ $100 \%$

$$
\begin{aligned}
& \text { TD Equity } 2014 \\
& =\frac{\operatorname{Rp~5.449.137.762,-}}{\operatorname{Rp} 4.768 .108 .355,-} \times 100 \% \\
& \quad=114 \%
\end{aligned}
$$

TD Equity 2015

$$
=\frac{\operatorname{Rp~12.497.056.244,-}}{\operatorname{Rp~5.778.682.347,-}} \times 100 \%
$$

$$
=216 \%
$$

Dari hasil perhitungan TD Equity yaitu dengan membandingkan total hutang dengan modal pada PT.Multi Sukses Makmur Perkasa tahun 2014 menunjukkan hasil rasio sebesar Rp 1.14hal ini menunjukkan bahwaperusahaan bisa menutupi Rp 1.14 hutang dengan modal yang dimiliki oleh perusahaan.

Untuk tahun 2015 TD Equity yaitu dengan membandingkan total hutang dengan modal pada PT.Multi Sukses Makmur Perkasa tahun 2015 menunjukkan hasil current ratio sebesar Rp 2.16 hal ini menunjukkan bahwa perusahaan bisa menutupi Rp 2.16 hutang dengan modal yang dimiliki oleh perusahaan. TD Equity pada tahun 2015 mengalami penurunan sebesar $102 \%$ dari tahun 2014. Penurunan ini disebabkan oleh kenaikan persentase pinjaman/ hutang perusahaan sebesar 56\% yang lebih besar dibandingkan dengan kenaikan modal perusahaan yang hanya sebesar $17 \%$.

\section{Debt Ratio}

Perhitungan Debt Ratio PT.Multi Sukses Makmur Perkasa adalah sebagai berikut:

Debt Ratio

$=\frac{\text { Total Hutang }}{\text { Total Assets }} \times 100 \%$

Debt Ratio 2014

$=\frac{\operatorname{Rp} 5.449 .137 .762,-}{\operatorname{Rp~10.235.246.117,-~}} \times 100 \%$

$=53 \%$

Debt Ratio 2015

$=\frac{\operatorname{Rp~12.497.056.244,--}}{\operatorname{Rp~18.275.738.591,-~}} \times 100 \%$

$=68 \%$

Dari hasil perhitungan Debt Ratio yaitu dengan membandingkan total Hutang dengan total Assets pada PT.Multi Sukses Makmur Perkasa tahun 2014 menunjukkan hasil rasiosebesar $53 \%$ atau $\mathrm{Rp} 0.53$ hal ini menunjukkan bahwa perusahaan mengandalkan $53 \%$ hutang dari pada asset atau modal dari dalam perusahaan.

Untuk tahun 2015 Debt Ratio yaitu dengan membandingkan total Hutang dengan total Assets pada PT.Multi Sukses Makmur Perkasa tahun 2014 menunjukkan hasil rasiosebesar $68 \%$ atau $\mathrm{Rp} 0.68$ hal ini menunjukkan bahwa perusahaan mengandalkan $68 \%$ hutang dari pada asset atau modal dari dalam perusahaan. Debt Ratio dari tahun 2014 ke 2015 mengalami kenaikan sebanyak 15\% ini menunjukan kinerja keuangan yang buruk terhadap perusahaan karena semakin tingginya rasio hutang dari tahun 2014 ke 2015.

Berdasarkan hasil rasio leverage, manajemen perusahaan dapat mengetahui seberapa besar aktiva yang dimiliki perusahaan berasal dari hutang atau modal, pada tahun 2014 dan 2015 hutang perusahaan meningkat diakibatkan jumah kewajiban yang naik pada tahun 2015 sebesar 55\% sedangkan tidak dibandingin dengan kenaikan aktiva. Untuk periode berikutnya sebaiknya perusahaan memperhatikan posisi leverage. Perusahaan juga perlu memperhitungkan besar kecilnya aktiva lancar yang perusahaan miliki agar mampu membayar hutang perusahaan. 


\section{Perhitungan Rasio Profitabilitas}

1. Gross Profit Margin (GPM)

GPM $=\frac{(\text { Penjualan Bersih }- \text { HPP })}{\text { Penjualan bersih }} \times 100 \%$

GPM $2014=$

$\frac{(\mathrm{Rp} 43.712 .648 .510-\mathrm{Rp} 41.640 .523 .618)}{\operatorname{Rp} 43.712 .648 .510} \times 100 \%$ $=4.7 \%$

GPM 2015=

$\frac{(\operatorname{Rp} 45.720 .565 .023-\operatorname{Rp} 43.545 .347 .940)}{\operatorname{Rp} 45.720 .565 .023} \times 100 \%=$ $5.1 \%$

Pada hasil perhitungan diatas dengan membandingkan penjualan bersih setelah dikurangi HPP dan penjualan bersih maka margin keuntungan kotor PT.Multi Sukses Makmur Perkasa tahun 2014 sebesar 4,7\% dan naik menjadi $5.1 \%$ pada tahun berikutnya. Kenaikan rasio keuntungan kotor ini menunjukkan bahwa perusahaan mampu menaikkan hasil penjualannya sebesar $0.4 \%$.

2. Net Profit Margin (NPM)

NPM $=\frac{\text { Laba Bersih }}{\text { Penjualan bersih }} \times 100 \%$

$\mathrm{NPM} 2014=\frac{R p 975.048 .466}{R p 43.712 .648 .510} \times 100 \%$

$=2.2 \%$

Berdasarkan hasil rasio profitabilitas, manajemen perusahaan dapat mengetahui seberapa besar kemampuan perusahaan dalam menghasilkan laba dan kemajuan kinerja perusahaan selama dua tahun terakhir, sehingga perusahaan dapat mengambil keputusankeputusan yang bertujuan untuk lebih meningkatkan kinerja perusahaan serta efisiensi dan efektivitas perusahaan dalam menjalankan operasinya.
NPM $2015=\frac{R p 1.023 .145 .987}{R p 45.720 .565 .023} \times 100 \%$ $=2,1 \%$

Net Profit Margin perusahaan dengan cara membandingkan laba bersih dan penjualan bersih perusahaan pada tahun 2014 menunjukkan hasil Net Profit Margin sebesar 2,2\% dan pada tahun 2015 menunjukkan hasil sebesar 2,1\%, besar penurunan hasil Net Profit Margin sebesar $0,1 \%$. Ini menunjukkan bahwa perusahaan mengalami penurunan laba bersih dari penjualan barang dikarenakan biaya operasional yang mengalami kenaikan sebesar $6,40 \%$.

$$
\begin{aligned}
& \text { 3. Return on Asset }(\mathrm{ROA}) \\
& \begin{aligned}
\text { ROA } & =\frac{\text { Laba Bersih }}{\text { Total Aktiva }} \times 100 \% \\
\text { ROA } 2014 & =\frac{R p 975.048 .466}{R p 10.004 .674 .122} \times 100 \% \\
& =9,7 \% \\
\text { ROA } 2015 & =\frac{R p 1.023 .145 .987}{R p 17.832 .465 .167} \times 100 \% \\
& =5,7 \%
\end{aligned}
\end{aligned}
$$

Return on Asset menunjukkan besarnya total aktiva yang digunakan untuk menghasilkan laba bersih. Return on Asset PT.Multi Sukses Makmur Perkasa pada tahun 2014 mengalami penurunan sebesar $4 \%$ hal ini disebabkan oleh penurunan laba yang diperoleh perusahaan. Penurunan laba ini disebabkan oleh kenaikan biaya operasional yang tidak diimbangi dengan kenaikan pendapatan yang diperoleh perusahaan

Dari hasil perhitungan rasio profitabilitas diatas menunjukkan bahwa laba perusahaan menurun sebagian besar diakibatkan oleh biaya operasional yang naik pada tahun 2015.Perusahaan sebaiknya dapat menekan biaya dengan melakukan evaluasi terhadap penggunaan biaya-biaya operasional yang telah dikeluarkan oleh perusahaan pada tahun-tahun yang telah berjalan, namun apabila biaya tidak dapat ditekan maka perusahaan harus menaikkan penjualan perusahaan agar laba perusahaan tidak menurun. 


\section{Kesimpulan dan Saran}

\section{Kesimpulan}

Menurut hasil analisis perbandingan rasio laporan keuangan pada PT.Multi Sukses Makmur Perkasa dapat disimpulkan bahwa :

1. Laporan keuangan disusun oleh PT.Multi Sukses Makmur Perkasa sebagai pertanggungjawaban manajemen atas pengelolaan sumber daya perusahaan selama satu periode akuntansi dalam hal ini periode dimulai 1 januari dan berakhir 31 desember.

2. Dilihat dari likuiditasnya, perusahaan mampu memenuhi hutang lancarnya walaupun kemampuannya cenderung menurun. Hal ini dapat dilihat dengan adanya penurunan rasio lancar sebesar Rp. 0,40 maupun rasio cepat sebesar Rp. 0,03. Penurunan ini diakibatkan oleh naiknya persentase kewajiban lancar diikuti oleh kenaikan aktiva lancar yang tidak sebanding.

3. Dilihar dari leverage, perusahaan mampu memenuhi hutang dengan aktiva yamg dimiliki perusahaan hanya sebesar $44 \%$, hal ini dikarenakan total hutang yang naik pada tahun 2015 sebesar $56 \%$ dan tidak diimbangi dengan kenaikan modal yang hanya $17 \%$ pada tahun 2015.

4. Dilihat dari profitabilitasnya, perusahaan dapat menghasilkan laba walaupun pada tahun 2015 laba yang dihasilkan hanya sebesar $20,28 \%$, hal ini dikarenakan adanya kenaikan biaya operasional sebesar $6,02 \%$ tanpa diikuti kenaikan hasil penjualan barang dagang perusahaan yang hanya naik sebesar $4,81 \%$.

\section{Saran}

Untuk menunjang kelancaran dan kesuksesan PT.Multi Sukses Makmur Perkasa, maka saran yang dapat penulis sampaikan adalah sebagai berikut :

1. Laporan keuangan yang telah disusun harusnya dapat dipertanggung jawabkan pada rapat evaluasi para pemegang saham atau rapat direksi.

2. Perusahaan harus bisa menaikkan tingkat likuiditasnya dari tahun ke tahun. Tingkat likuiditas yang baik adalah 2:1 dimana aktiva lancar yang digunakan untuk membiayai hutang diusahakan lebih besar dari hutang lancarnya.

3. Perusahaan sebaiknya memperhatikan besar kecilnya aktiva lancar yang perusahaan miliki agar mampu membayar hutang perusahaan.

4. Perusahaan sebaiknya dapat meningkatkan penjualannya dan menekan biaya-biaya yang dikeluarkan oleh perusahaan, sehingga dapat meningkatkan laba perusahaan dari tahun ke tahun. Untuk menekan biaya-biaya yang dikeluarkan, perusahaan harus mengadakan evaluasi kinerja perusahaan secara berkala atau setiap akhir tahun periode dalam hal ini setelah laporan tahunan dibuat dan dilakukan audit laporan keuangan. Apabila dengan segala kebijakan perusahaan tidak dapat menekan biaya, maka perusahaan perlu meningkatkan pendapatan dari penjualan barang dagang maupun dari pendapatan lain-lain.

\section{DAFTAR PUSTAKA}

Akuntansi, (2015, 27 oktober), "Pengertian Hutang dan Jenis-Jenis Hutang", http://www.akutansi.com diakses 16 Maret 2017

Irham Fahmi,(2013), Analisis Laporan Keuangan, Bandung:ALFABETA.

Mardiasmo, (2008), Akuntansi Keuangan Dasar, Yogyakarta :BPFE.

Mulyadi, (2007), Sistem Perencanaan dan Pengendalian Manajemen.Jakarta:Salemba Empat.

Rudianto, (2012), Pengantar Akuntansi, Jakarta: Erlangga.

Sawir,(2005), Analisis kinerja Keuangan dan Perencanaan Keuangan, Jakarta:Erlangga.

Soemarso, (1999), Akuntansi Suatu Pengantar, Jakarta : Rineka Cipta.

Wibowo dan Abubakar Arif, (2005), Pengantar Akuntansi II, Jakarta : Grasindo. 